\title{
SUBACUTE EFFECTS OF TRANSGENIC Cry1Ab BACILLUS THURINGIENSIS CORN LITTER ON THE ISOPODS TRACHELIPUS RATHKII AND ARMADILLIDIUM NASATUM
}

\author{
Bryan W. Clark, Kelsey R. Prihoda, and Joel R. Coats* \\ Department of Entomology and Interdepartmental Toxicology Program, Iowa State University, 115 Insectary, Ames, Iowa 50011, USA
}

(Received 9 August 2005; Accepted 8 March 2006)

\begin{abstract}
Laboratory studies were conducted to investigate the subacute effects of transgenic Cry1 Ab corn leaf material containing Bacillus thuringiensis (Bt) protein on the terrestrial isopods Trachelipus rathkii and Armadillidium nasatum. Survival and growth were measured for eight weeks in isopods fed leaf material of two Bt11 corn varieties, two Monsanto 810 (Mon810) corn varieties, and the isolines of each. Total lipid and protein content of the organisms was measured to examine effects on energetic reserves. Armadillidium nasatum individuals in all treatments responded similarly. For T. rathkii, no statistically significant effect of Bt was observed, but statistical differences were observed in growth between hybrids. Protein and sugar content of the food were found to be correlated with the differences in growth for T. rathkii. Total protein content was higher in T. rathkii and A. nasatum fed material with higher protein and sugar content. A trend toward less growth in T. rathkii on Bt corn varieties versus their isolines triggered a concentration-response assay with purified Cry1 Ab protein. No adverse effects of purified Bt protein were observed. These results indicate that little hazard to $T$. rathkii and A. nasatum from Bt corn leaf material from these hybrids exists. However, nutritional differences in corn hybrids contributed to differences in isopod growth.
\end{abstract}

Keywords-Transgenic corn Isopods Bacillus thuringiensis protein Nontarget effects Energetic reserves

\section{INTRODUCTION}

Bacillus thuringiensis (Bt) is an aerobic, gram-positive, spore-forming soil bacterium that produces insecticidal crystal proteins. The spores and protein crystals from Bt have been used as microbial insecticides for over 40 years [1]. Different subgroups of $\mathrm{Bt}$ proteins exist, with activities that are thought to be somewhat specific to different insect orders. For example, the Cry1 proteins are active against Lepidoptera, and the Cry3 proteins are active against Coleoptera. Genes encoding several of the Bt toxins have been engineered into a variety of crop plants as inherent insect protectants. This use of Bt, through the expression of genes encoding for production of the Cry protein toxins in transgenic plants, has increased substantially in agroecosystems, especially since 1999. For example, 2.8 million ha of Bt corn (Zea mays) were planted in the United States in 1998, compared to 9.7 million ha one year later, and about 12 million ha by 2002 [2,3]. Worldwide, the area on which Bt corn was grown increased from around 3 million ha in 1998 to 15.5 million ha in 2003 [3,4].

Transgenic plant-produced Bt proteins can enter the environment in a variety of ways after planting. The Bt protein is incorporated into soil with plant tissue postharvest, by sloughing of root cells, and potentially through the release of exudates from roots; therefore, the soil fate of the protein is a key parameter governing exposure of nontarget organisms in the environment. Saxena and Stotzky [5] reported the presence of the protein in secretions from transgenic corn roots. Additionally, Stotzky and coworkers [6-10] demonstrated that Bt proteins were adsorbed to soil components, especially clays, and were protected from degradation but retained insecticidal activity. Although conflicting results have been found in assessing Bt protein persistence in soil, previous studies gen-

* To whom correspondence may be addressed (jcoats@iastate.edu). erally indicate that the dissipation is biphasic; the concentration of protein rapidly declines and then the remaining portion dissipates at a much slower rate [11-14]. In a series of microcosm experiments, Palm et al. [12] found that 10 to $40 \%$ of the protein remained at the end of a $28-d$ period. Using an insect bioassay, Sims and Ream [13] determined that approximately $20 \%$ of the initial Cry2A bioactivity remained after $120 \mathrm{~d}$ of incubation in soil. Similarly, Tapp and Stotzky [9] observed that the insecticidal activity of Bt subspecies kurstaki protein in soil was retained for more than six months. In a recent study using corn tissue within field-buried litter bags, it was observed that degradation of Cry1 Ab protein in corn tissue is slow, and a portion of the protein remained until the following spring [15]. Based on these studies and the fact that the $\mathrm{Bt}$ protein is expressed throughout the growing season of the plant, it is conceivable that soil-dwelling and litter-dwelling organisms are subject to long-term exposure to Bt proteins. Therefore, it is necessary to establish whether a hazard to soil and litter biota from long-term exposure to Bt protein exists.

Very few studies have been conducted that examine the effects of Bt proteins on decomposers. Decomposers are an important group to study, considering the high likelihood of exposure to Bt proteins for those soil organisms. Most of the studies conducted have focused on earthworms, springtails, and some microbes [16-21].

Isopods are an important component of the soil ecosystem and have been fairly widely used in terrestrial-effects testing $[22,23]$. Isopods are found throughout the world in a variety of terrestrial habitats [24]. They are macroarthropods whose main ecological role is in decomposition, especially in the fragmentation of dead plant material [23,24]. Their feeding activity prepares the plant material for mesofaunal decomposers such as mites and springtails and for microbial breakdown $[22,25,26]$. The species of pillbug used in these studies was Armadillidum nasatum (Budde-Lund, 1885), and the spe- 
Table 1. Specific Bacillus thuringiensis event or hybrid used for each treatment and concentration of Bt protein in the leaf material of each Bt line ${ }^{a}$

\begin{tabular}{|c|c|c|c|c|c|}
\hline Treatment description & Event (or isoline) & Maturity & Variety (hybrid) & Brand $^{\mathrm{b}}$ & Bt concn. $(\mu \mathrm{g} / \mathrm{g})^{\mathrm{c}}$ \\
\hline Bt11-90 (Bt+) & Bt11 & $90-d$ & $\mathrm{~N} 2555 \mathrm{Bt}$ & NK (Syngenta) & $2.40 \pm 0.07$ \\
\hline Bt11-90 (Bt-) & Isoline Bt11 & 90-d & N2555-F95 & NK (Syngenta) & - \\
\hline $\mathrm{Bt} 11-108(\mathrm{Bt}+)$ & Bt11 & 108-d & N58-D1 & NK (Syngenta) & $2.69 \pm 0.08$ \\
\hline Bt11-108 (Bt-) & Isoline Bt11 & 108-d & N58-F4 & NK (Syngenta) & - \\
\hline Mon810-90 $(\mathrm{Bt}+)$ & Mon810 & 90-d & $38 \mathrm{~A} 25$ & Pioneer (DuPont) & $2.19 \pm 0.07$ \\
\hline Mon810-90 (Bt-) & Isoline Mon810 & 90-d & 38A24 & Pioneer (DuPont) & - \\
\hline Mon810-108 $(\mathrm{Bt}+)$ & Mon810 & 108-d & 34M95 & Pioneer (DuPont) & $2.20 \pm 0.06$ \\
\hline Mon810-108 $(\mathrm{Bt}-)$ & Isoline Mon810 & 108-d & 34M94 & Pioneer (DuPont) & - \\
\hline
\end{tabular}

a Values are mean \pm standard error.

b Syngenta (Wilmington, DE, USA); Monsanto (St. Louis, MO, USA).

c Bt concentration calculated as mass of protein/wet weight of leaf material.

cies of sowbug used in these studies was Trachelipus rathkii (Brandt, 1833). Armadillidium nasatum and T. rathkii are relatively abundant isopods, particularly in the corn-growing region of the central United States, with fairly general habitat requirements, making them good representative test organisms [27].

Very little work exists on the effects of Bt proteins on isopods. Previously, Sims [28] examined the host activity spectrum of purified Cry2A protein against a battery of insects and one isopod, the sowbug Porcellio scaber. No effect was observed on $P$. scaber. Another study examined the effects of consumption of transgenic Bt corn on P. scaber [29]. The authors found mixed results, but, in general, no detrimental effects of Bt corn on the isopod were observed.

Because of the potential for long-term exposure and the lack of studies on the effects of $\mathrm{Bt}$ transgenic crops, it is important to assess the subacute impacts on members of the soil and litter community. Isopods represent an important group of decomposer organisms that have not been investigated in this regard. In addition, very few of the previous bioassays assessing the effects of Bt on any group of organisms have incorporated subacute endpoints of toxicity. The current studies were developed to provide a template for assessment of subacute effects of transgenic Bt plant material on isopods, using a more realistic exposure scenario. The objectives of the current studies were to examine the subacute effects of Bt corn leaf material on the isopods A. nasatum and $T$. rathkii, using multiple Bt corn lines for a broad comparison, to improve and adapt existing methodologies for use with transgenic crops, to investigate if there are nutritional differences between the corn types that affect responses of the isopods, and to determine if measurement of energetic reserves, such as lipid and protein, can be used as biomarkers of any effects observed. This information will be useful in better characterizing any effects of Bt crops on these soil invertebrates and provide methodology that can be used to evaluate other Bt proteins and future transgenic crops.

\section{MATERIALS AND METHODS}

\section{Corn material}

Eight seeds each of the varieties of corn listed in Table 1 were planted in 19-L plastic buckets filled with Sun Gro ${ }^{\circledR}$ Sunshine LC1 Professional Mix potting soil (Sun Gro Horticulture Distribution, Bellevue, WA, USA). The varieties planted consisted of two maturities each of Bt11 (Syngenta, Wilmington, DE, USA) and Mon810 (Monsanto, St. Louis, MO, USA). Each of these varieties produces Cry1 Ab Bt proteins.
These are two of the major commercially grown varieties of Cry1Ab corn. The two maturities of each variety are bred for a 90 - or a 108-d growing season. In addition, the nearest genetic equivalent, or near-isoline, of each Bt line was used. The plants were grown in the greenhouse on a 16:8-h light:dark cycle at $27^{\circ} \mathrm{C}$ (light) and $20^{\circ} \mathrm{C}$ (dark). Plants were watered two to three times weekly, in a manner that ensured adequate moisture. Plants were fertilized twice during the first two months of the growing period with Miracle-Gro ${ }^{\circledR}$ (The Scotts Company, Marysville, OH, USA) at the rate directed on the label. When the plants had tassels (VT stage), the top three groups of leaves were cut from the main stem. The plants were harvested at tasseling and the newest leaves used because this is the stage and location on the plant that should have the highest concentration of $\mathrm{Bt}$ protein [30]. Once leaf material from all the plants in a treatment was collected, the leaves were cut into smaller pieces of about $1 \mathrm{~cm}^{2}$ to be ground. Ground plant material was prepared by grinding the leaf material with a mortar and pestle under liquid nitrogen. The corn material was not truly freeze-dried or lyophilized; the liquid nitrogen was used only to simplify grinding, and the corn material was still green and moist after processing. Samples were stored in the freezer at $-15^{\circ} \mathrm{C}$ until use in the bioassays or in analysis of Bt protein content and nutrient constituents.

\section{Organisms}

Pillbugs (A. nasatum) and sowbugs (T. rathkii) were collected in a greenhouse bay at Iowa State University that had not received pesticide treatment in more than four years. Captured individuals were divided on the basis of gross morphological characteristics. Culturing initially occurred in a mixed species situation. Isopods were cultured in terrariums filled to a depth of 4 to $5 \mathrm{~cm}$ with potting soil. Trays filled with a mixture of hydrated $\mathrm{CaSO}_{4}$ and activated charcoal were placed in the bottom of the terrarium to absorb excess nitrogen. Each terrarium had multiple shards of clay pot as shelter. The isopods received raw potato slices as their primary food source but were also given guinea pig food and ground cereal leaves (cerophyl; Fisher, Chicago, IL, USA). The terraria were kept in the greenhouse on a $16: 8$-h light:dark cycle at $27^{\circ} \mathrm{C}$ (light) and $20^{\circ} \mathrm{C}$ (dark). Prior to use in the bioassays, neonates were removed from the culture and maintained separately for $30 \mathrm{~d}$.

\section{Soil description}

The soil used for each assay was a field-collected agronomic soil from a reference field at the Iowa State University $\mathrm{Ag}$ Engineering/Agronomy Farm, about four miles west of Ames, 
Iowa, USA $\left(42^{\circ} 01^{\prime} \mathrm{N}, 93^{\circ} 45^{\prime} \mathrm{W}\right)$. The field is known to have had no pesticide application for more than 30 years. Soil physiochemical properties were analyzed by Midwest Laboratories (Omaha, NE, USA) using standard protocols. The soil was classified as a composite of Nicollet (aquic hapludoll) and Webster (typic haplaquoll) with a sandy loam texture [31]. It was $60 \%$ sand, $22 \%$ silt, and $18 \%$ clay. The organic matter content was $2.7 \%$, and field capacity was determined to be $17 \%$ (water/dry soil). After collection, the soil was sieved (2.83-mm mesh size) and stored at $4^{\circ} \mathrm{C}$ for less than $45 \mathrm{~d}$, until use in the bioassays. Prior to testing, the soil was allowed to air-dry to greater than $97 \%$ solid, then moistened to near field capacity, and then allowed to air-dry again. This procedure was intended to reduce soil fauna and prevent competition or predation on the test organisms.

\section{Enzyme-linked immunosorbent assay measurements of soil and corn}

The soil from the reference field was analyzed by enzymelinked immunosorbent assay (ELISA) prior to use in the assays to ensure that no background level of Bt protein existed from previous use of $\mathrm{Bt}$ insecticide or from naturally occurring $B$. thuringiensis. The soil was extracted using a high-pH and high-salt buffer as used by Palm et al. [11], and the concentration of Bt protein was confirmed to be below detection limits by use of the Envirologix Cry1Ab/1Ac Quantiplate Kit (Portland, ME, USA). Absorbance was measured on a THERMOmax microplate reader with quantification by SOFTmax software (Molecular Devices, Sunnyvale, CA, USA). The procedure included with the kit was followed in conducting the ELISA measurements, except the extraction buffer previously described was used rather than the buffer provided with the kit. Samples of the ground corn leaves were also measured at both the beginning and the end of the test periods for each assay, using the same kits.

\section{ELISA measurement of CrylAb residue in isopods}

At the conclusion of the various bioassays, 4 to 12 isopods from each treatment were randomly selected to be tested for Bt residues. The isopods were combined and placed in a glass homogenizing tube under $0.5 \mathrm{ml}$ of the high-salt buffer $(\mathrm{pH}$ 8.8) described previously. Organisms were ground for $1 \mathrm{~min}$ using a Teflon ${ }^{\circledR}$ homogenizer driven by a benchtop drill press. The homogenizer was rinsed with $0.5 \mathrm{ml}$ of buffer, and the solutions were allowed to sit at room temperature for $1.5 \mathrm{~h}$ to further break down the tissue. The solutions were transferred to microcentrifuge tubes and centrifuged for $5 \mathrm{~min}$. A sandwich-type ELISA was conducted on three subsamples of supernatant using the Envirologix kit and methods described previously.

\section{Plant material nutritional measurements}

Nutritional measurements of fat by gas chromatography, sugar profile by high-pressure liquid chromatography, and total protein for all eight corn varieties and the guinea pig food (Nature's Gold ${ }^{(\mathbb{N}}$, Hartz Mountain, Secaucus, NJ, USA) and cerophyl mixture were conducted by Medallion Labs (Minneapolis, MN, USA), using standard methods [32-34].

\section{Isopod survival, growth, and development}

Both isopod studies were conducted using the same design and methodology. Juvenile growth and development were chosen as sensitive, subacute endpoints. The test design utilized ten treatments, consisting of the eight corn varieties and a control, with 20 replicates per treatment. Each replicate consisted of one individually housed and fed isopod. In addition to the isoline control for each Bt corn line, a control was used that incorporated optimal food. Individuals in the control treatment received a 50:50 (weight/weight) mixture of commercial guinea pig food and cerophyl, a mixture of ground, dried cereal leaves. The control food mixture was found to yield large positive growth in preliminary studies (data not shown).

Test units consisted of 20-ml, 2.5-cm-diameter glass scintillation vials with two 2-mm holes in the lid. Agronomic soil $(3.5 \mathrm{~g})$ was added to each vial. Prior to the test, $1.3 \mathrm{~g}$ of water was added to each unit. Thereafter, moisture was maintained at approximately $75 \%$ of field capacity. Individual isopods were weighed and randomly assigned to a treatment. The $A$. nasatum ranged in mass from 3.0 to $7.8 \mathrm{mg}$, and the $T$. rathkii ranged from 3.0 to $8.0 \mathrm{mg}$. The initial weights were tested using SAS ${ }^{\circledR}$, Version 8.2 (SAS Institute, Cary, NC, USA), to ensure that the average weights of the individuals in the treatments were not significantly different prior to beginning the assay. The test units were arranged in a randomized complete block design and placed in a growth chamber at $24^{\circ} \mathrm{C}$ on a 16 : 8-h light:dark cycle of indirect light for eight weeks. Individuals were fed ad libitum with the appropriate food, either corn leaf material or the control food mixture. The test units were monitored daily for moisture and mortality of the isopods. Weekly, each individual was removed from the test unit, cleaned of soil, and weighed. Molting was also recorded at this time. Mass of any individual that died was recorded if the individual was known to have died within $1 \mathrm{~d}$ of the weighing day. On the final day of the test, each individual was removed from the unit, cleaned, weighed, placed in a microcentrifuge tube, and stored at $-15^{\circ} \mathrm{C}$ for later analysis.

\section{Concentration-response assay: T. rathkii survival, growth, and development}

In order to determine if the apparent trend of a negative effect of Bt corn material observed in the first assay (results presented subsequently) could be a direct result of the Cry $1 \mathrm{Ab}$ protein, a concentration-response bioassay was conducted using $T$. rathkii. Approximately $7 \mathrm{~g}$ of agronomic soil were added to each $25-\mathrm{ml}$ glass vial test chamber. Distilled water $(1.3 \mathrm{ml})$ was added to each chamber to bring the soil to $75 \%$ of field moisture capacity. The chambers were held in an incubator maintained at $21 \pm 1^{\circ} \mathrm{C}$ for one week to allow moisture equilibration before adding $T$. rathkii. After equilibration, one $T$. rathkii was added to each chamber, 20 per treatment. Organisms ranged in starting weight from 2.6 to $7.1 \mathrm{mg}$.

Purified Cry1 Ab protein (purchased from Marianne Carey, Case Western Reserve University, Cleveland, OH, USA) was added to the $T$. rathkii diet by fortifying $2 \mathrm{~g}$ of a 50:50 (weight/ weight) mixture of ground guinea pig food:cerophyll with 1.5 $\mathrm{ml}$ of the appropriate concentration of Cry $1 \mathrm{Ab}$ protein in phosphate-buffered saline with Tween (PBST) to achieve a final Cry1Ab concentration of $0,3,10,40$, or $100 \mu \mathrm{g} / \mathrm{g}$ in the diet. The control food was treated with $1.5 \mathrm{ml}$ of PBST. The diet was placed in a desiccator overnight to dry. The dry food was ground with a mortar and pestle, and approximately $65 \mathrm{mg}$ of the appropriate treated diet were added once weekly to each chamber. Samples of the prepared food were extracted and analyzed periodically via ELISA to determine the concentration of Cry1 Ab to which the organisms were exposed. The 
measured concentrations were found to correspond to the concentration desired.

Test chambers were maintained in an incubator at $21 \pm 1^{\circ} \mathrm{C}$ for eight weeks. Incubator temperature and chamber moisture were checked daily. The organisms were monitored daily and weighed weekly; mortality and molting were recorded. At the end of the study, the surviving $T$. rathkii were cleaned, weighed, placed into microcentrifuge tubes, and randomly designated for measurement of total lipid content or Cry1 $\mathrm{Ab}$ whole body residue. Each individual was stored at $-15^{\circ} \mathrm{C}$ until analysis.

\section{Measurement of energetic reserves}

For both species and all bioassays, four to seven individuals from each treatment were selected for total lipid content analysis. Total lipid content was determined absorptimetrically in the manner described by Donker [35] using cholesterol as a standard. Each isopod was placed in a homogenizer containing $1 \mathrm{ml}$ of chloroform:methanol:water (2:2:1, v/v/v) extraction solution. The organisms were homogenized for $1 \mathrm{~min}$ using a benchtop drill press. After separation of the chloroform and methanol/water layers, the chloroform layer was removed and washed with sodium sulfate. The methanol/water layer was extracted two more times with $0.5 \mathrm{ml}$ chloroform. The chloroform/sodium sulfate mixture was filtered to remove the sodium sulfate, and the chloroform was evaporated to dryness using an N-EVAP ${ }^{\circledR}$ (Organomation Associates, Berlin, MA, USA). The residual lipids were dissolved in $0.5 \mathrm{ml}$ concentrated sulfuric acid, and the mixture was placed in a water bath at approximately $84^{\circ} \mathrm{C}$ for $10 \mathrm{~min}$ and cooled. Cholesterol standards were dissolved in chloroform, and concentrated sulfuric acid was added to achieve a final cholesterol concentration of $0.1,0.5,1.0,3.0$, and $10.0 \mathrm{mg} / \mathrm{ml}$. Standards were heated and cooled in the same manner as the samples. A 0.1 $\mathrm{ml}$ aliquot of each cooled sample or standard was added to a test tube containing $2.0 \mathrm{ml}$ of phosphoric acid-vanillin reagent (1.2 $\mathrm{g}$ vanillin dissolved in $200 \mathrm{ml}$ distilled water added to $800 \mathrm{ml}$ concentrated phosphoric acid) and mixed thoroughly. The phosphoric acid-vanillin reagent served as a blank. The resulting pink color was allowed to generate for $30 \mathrm{~min}$, and three 200- $\mu$ l subsamples from each sample, blank, and standard were plated on a 96-well plate. The absorbance was read on a Bio-Tek Powerwave HT (Bio-Tek Instruments, Winooski, VA, USA) plate reader at $540 \mathrm{~nm}$.

In each bioassay, except the $T$. rathkii concentration-response test, five to seven individuals from each treatment were randomly selected for determination of total protein content. Not enough individuals were available to perform this assay in the concentration-response test because lipid and Bt protein concentration were determined to be more interesting endpoints. Total protein was measured following the methods provided with a Total Protein Kit (Sigma, St. Louis, MO, USA), which utilized Peterson's Modification of the Micro-Lowry method. In brief, each individual was placed in a glass homogenizer tube containing $1 \mathrm{ml}$ of distilled water and ground for 1 min using a benchtop drill press. Protein standards were prepared with bovine serum albumin to achieve protein concentrations of 50,100, 200, 300, and $400 \mu \mathrm{g} / \mathrm{ml}$. A blank was prepared containing only distilled water. One milliliter of Lowry's reagent was added to each sample, standard, or blank, and this solution was mixed well and incubated for $20 \mathrm{~min}$ at room temperature. A 500- $\mu$ l aliquot of Folin and Ciocalteu's phenol reagent was added while mixing, and color was allowed to develop for $30 \mathrm{~min}$. Samples were brought to a 6-ml final volume by adding $3.5 \mathrm{ml}$ of distilled water. Three $200-\mu \mathrm{l}$ subsamples of each sample, standard, or blank were added to a 96-well plate. Absorbance was read at $650 \mathrm{~nm}$ within $30 \mathrm{~min}$ on a THERMOmax plate reader with quantification using SOFTmax software (Molecular Devices).

\section{Statistical analysis}

Each assay was conducted as a randomized complete block design. Individuals were randomly assigned to a treatment, and each treatment was represented once within a block. Blocks were created as rows within the growth chamber to account for positional effects. The resulting growth data were plotted against time and found to fit an exponential growth curve, as would be expected for early-life-stage growth. The data were transformed on the natural log scale. The percentage change in mass was determined and will be referred to as change in mass. Additionally, the slope of the natural loglinear growth curve was determined and will be referred to as growth rate. These two measures are highly related but do have differences. The percentage change in mass allows for a correction based on the variability of starting mass of the isopods. Larger isopods tended to grow faster than smaller, so using percentage change in mass would correct for that bias. However, any isopod that did not reach the end of the eightweek period was not included in the percentage change analysis, so isopods that died or were lost represent a loss in data and statistical power. The measurement of slope of the growth curve can be conducted from as little as two data points, and therefore a slope was obtained for all 20 individuals in each treatment. It is important to note that using a slope generated by a smaller number of data points does introduce more error than using the slopes of those individuals that survived until the end of the test. The analysis of the growth rate data was conducted both by using all the data and by omitting the data for individuals that died during the test. No significant differences between the two methods were found in the results, so the results reported for slope are based on the usage of data from every individual in the test. The data for all the responses (change in mass, growth rate, total lipid, total protein) are reported as the average plus or minus the standard error and were analyzed using analysis of variance in the general linear method procedure. In an additional analysis, the effects of nutritional parameters were determined using a multiple regression model in the general linear method procedure that included all three parameters (protein, sugar, and fat) and their interactions. All analyses were performed using SAS Version 8.2.

\section{RESULTS}

\section{ELISA measurements of soil, corn, and Bt residue in isopods}

The ELISA measurements of the soil confirmed that no measurable background level of Bt protein was present in the soils used in the test. The level of Cry1 Ab protein measured in the leaf material of each corn line is shown in Table 1. The ELISA measurements of whole organism extracts of isopods yielded no detection of the Bt protein for either species.

\section{Plant material nutritional measurements}

The material from the different corn varieties had relatively low amounts of the nutrients for which analyses were performed. The control food had higher amounts of total protein, 
Table 2. Total protein, fat, and sugar of each corn line and control food ${ }^{\mathrm{a}}$

\begin{tabular}{lccc}
\hline Treatment & Total protein $(\%)$ & Total fat $(\%)$ & Total sugar $(\%)$ \\
\hline Bt11-90 $(\mathrm{Bt}+)$ & $3.22 \pm 0.003$ & $0.13 \pm 0.01$ & 0.0 \\
Bt11-90 $(\mathrm{Bt}-)$ & $2.36 \pm 0.002$ & $0.64 \pm 0.03$ & 0.0 \\
Bt11-108 $(\mathrm{Bt}+)$ & $2.18 \pm 0.002$ & $0.56 \pm 0.02$ & 0.0 \\
$\mathrm{Bt11}-108(\mathrm{Bt}-)$ & $2.97 \pm 0.003$ & $0.60 \pm 0.02$ & 0.0 \\
Mon810-90 $(\mathrm{Bt}+)$ & $2.23 \pm 0.002$ & $0.54 \pm 0.02$ & $0.49 \pm 0.02$ \\
Mon810-90 $(\mathrm{Bt}-)$ & $1.85 \pm 0.002$ & $0.50 \pm 0.02$ & $0.78 \pm 0.02$ \\
Mon810-108 $(\mathrm{Bt}+)$ & $1.99 \pm 0.002$ & $0.54 \pm 0.02$ & $0.74 \pm 0.02$ \\
Mon810-108 $(\mathrm{Bt}-)$ & $1.74 \pm 0.002$ & $0.35 \pm 0.01$ & 0.0 \\
Control (positive and negative) & $23.0 \pm 0.023$ & $2.54 \pm 0.10$ & $4.46 \pm 0.13$ \\
\hline
\end{tabular}

a Values are mean \pm standard error. All values are expressed as weight/weight percentages.

total fats, and total sugars. In three out of four cases, the Bt line had a higher percentage total protein than the corresponding isoline. Most of the corn material had very little to no measurable sugars. The nutritional measurements are presented in Table 2.

Isopod (A. nasatum and T. rathkii) survival, growth, and development

For A. nasatum, none of the treatments caused significant differences in mortality (data not shown), and no Bt corn treatments varied from their isoline $(p>0.05)$. Mortality was $10 \%$ or lower in all treatments. No consistent effect on molting was observed. The average percentage change in mass (change in mass) and the growth rate for each treatment are shown in Table 3. As is seen in these data, any observed effects on change in mass and growth rate should be similar if the average starting weights of the individuals in the treatments are similar. Most of the individuals exhibited a positive weight change, although a few among the treatments showed no change or decrease in weight. Neither change in mass nor change in growth rate was significantly different from the control for individuals fed any of the eight corn lines ( $p>0.05$, Dunnett's adjustment).

No statistical differences were observed in change in mass or growth rate between any Bt line and its isoline $(p>0.05)$. Also, no differences were observed in either growth measure when $\mathrm{Bt}$ was ignored and the four Bt/isoline hybrid pairingsBt11-90 (Bt \pm ), Bt11-108 (Bt \pm ), Mon810-90 (Bt \pm ), Mon810$108(\mathrm{Bt} \pm)$-were compared $(p>0.05)$.

For $T$. rathkii, no significant differences were observed in mortality observed between treatments, nor were any effects on molting observed (data not shown, $p>0.05$ ). Mortality was $15 \%$ or lower in all treatments and $10 \%$ in the control. Furthermore, several of the individuals were lost because of difficulty in removing the soft-bodied sowbugs from the test chambers without damaging the individual. The change in mass is shown in Figure 1, and the average slope of the growth rate for each treatment is shown in Table 4. Most individuals in the test had a positive change in mass; however, a few individuals either lost weight or did not gain weight significantly. Unlike for the pillbugs, several of the treatments resulted in sowbug growth that was different from the controls. With the exception of Bt11-108 (Bt-), the change in mass was statistically smaller than that of the individuals in the control treatments for all the corn varieties $(p<0.05)$. The growth rate was also lower than that for controls in the corn treatments, but the difference was not statistically significant for any of the treatments.

Statistically, no negative effect of the Bt corn lines was observed, in comparison to their isolines. Comparisons of change in mass and growth rate showed no statistical differences for any of the four corn pairings $(p>0.05)$. However, as seen in Figure 1 and Table 4, the change in mass and growth rate is numerically greater in the isolines for three of the four pairings. Because this trend indicated a possible negative effect of the Bt protein, it triggered the dose-response-type assay that was conducted with $T$. rathkii.

When presence of the $\mathrm{Bt}$ protein was ignored and $\mathrm{Bt}$-isoline pairs were compared as one corn hybrid pairing, differences in growth were observed. Individuals fed Bt11-108 (Bt \pm ) experienced a percentage change in mass that was $37 \pm 10 \%$ greater than those fed Mon810-90 $(\mathrm{Bt} \pm)$ and $39 \pm 10 \%$ greater than those fed Mon810-108 (Bt \pm ) $(p=0.0007$ and $p=$ 0.0005). Additionally, the change in mass for Bt11-108 (Bt \pm ) was nearly significantly larger than $\mathrm{Bt} 11-90(\mathrm{Bt} \pm)(p=$ $0.0555)$. These statistical differences were not as pronounced for the measurement of growth rate. Individuals fed the Bt11$108(\mathrm{Bt} \pm)$ treatment still had a statistically higher growth rate

Table 3. Average percentage change in mass, growth rate, total lipid, and total protein of Armadillidium nasatum fed Bt11 corn, Mon810 corn, non-Bt corn, or a control ${ }^{\mathrm{a}}$

\begin{tabular}{lcccc}
\hline Treatment & Mass change $(\%)$ & Growth rate $($ slope $)$ & Total lipid $\mu \mathrm{g} / \mathrm{mg}(n)$ & Total protein $\mu \mathrm{g} / \mathrm{mg}(n)$ \\
\hline Bt11-90 $(\mathrm{Bt}+)$ & $404 \pm 39$ & $0.2089 \pm 0.0157$ & $33 \pm 11(7)$ & $64 \pm 5(7)$ \\
$\mathrm{Bt11-90}(\mathrm{Bt}-)$ & $456 \pm 38$ & $0.2063 \pm 0.0160$ & $47 \pm 18(6)$ & $62 \pm 3(6)$ \\
Bt11-108 $(\mathrm{Bt}+)$ & $444 \pm 38$ & $0.2174 \pm 0.0113$ & $24 \pm 9(6)$ & $57 \pm 4(7)$ \\
Bt11-108 $(\mathrm{Bt}-)$ & $421 \pm 36$ & $0.2148 \pm 0.0103$ & $31 \pm 8(7)$ & $81 \pm 11(7)$ \\
Mon810-90 (Bt+) & $465 \pm 38$ & $0.2272 \pm 0.0076$ & $41 \pm 10(7)$ & $62 \pm 6(7)$ \\
Mon810-90 (Bt-) & $494 \pm 38$ & $0.2164 \pm 0.0157$ & $13 \pm 8(4)$ & $54 \pm 2(6)$ \\
Mon810-108 (Bt+) & $483 \pm 47$ & $0.2221 \pm 0.0131$ & $28 \pm 8(6)$ & $58 \pm 6(6)$ \\
Mon810-108 (Bt-) & $462 \pm 35$ & $0.2171 \pm 0.0144$ & $25 \pm 8(5)$ & $62 \pm 4(6)$ \\
Control & $501 \pm 50$ & $0.2231 \pm 0.0157$ & & $62 \pm 5(5)$ \\
\hline
\end{tabular}

\footnotetext{
a Values are mean \pm standard error.
} 


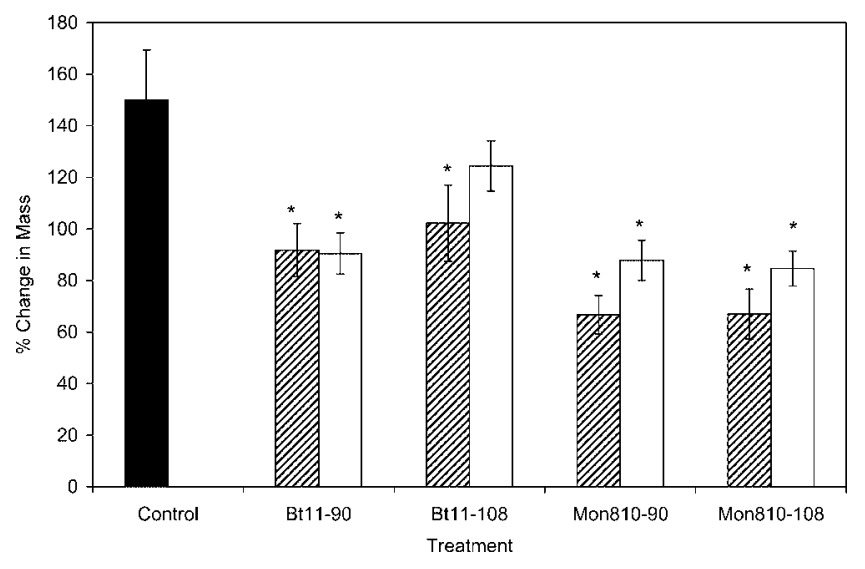

Fig. 1. Average percentage change in mass of Trachelipus rathkiifed Bt11 corn, Mon810 corn, or a control. Black bar, control; hatched bars, Bt corn lines; white bars, isolines. Error bars are equal to standard error. Treatments marked with $*$ are significantly different from the control treatment ( $p<0.05$, Dunnett's adjustment). No statistically significant differences exist between any $\mathrm{Bt}$ line and its isoline.

than those fed Mon810-108 (Bt \pm ) $(p=0.0465)$. However, for the comparisons of $\mathrm{Bt11-108}(\mathrm{Bt} \pm)$ with $\mathrm{Bt} 11-90(\mathrm{Bt} \pm)$ or Mon810-90 (Bt \pm ), the difference was not statistically significant $(p>0.05)$.

Concentration-response assay: T. rathkii survival, growth, and development

No significant $(p>0.05)$ differences were observed in mortality or growth found between any of the treatment groups, so a concentration-dependent effect of Cry1 Ab protein on $T$. rathkii growth does not appear to exist. Less than 5\% mortality was observed in all treatments and $10 \%$ in the control. Twenty percent mortality was observed at highest dose of protein, which may indicate some chronic toxicity. However, that concentration greatly exceeds anything that would occur in the field. The change in mass and the growth rate for each treatment are shown in Table 5. All individuals exhibited a positive change in mass.

\section{Effect of nutritional content}

Both protein and sugar content had a statistically significant effect on the change in mass $(p=0.0130$ and $p=0.0055)$ and growth rate of the sowbugs ( $p=0.0214$ and $p=0.0492$ ). Protein and sugar content were both positively correlated with change in mass and slope of the growth curve.

Table 4. Growth rate and total protein of Trachelipus rathkii fed Bt11 corn, Mon810 corn, non-Bt corn, or a control ${ }^{\mathrm{a}}$

\begin{tabular}{lcc}
\hline Treatment & Growth rate (slope) & $\begin{array}{c}\text { Total protein, } \\
\mu \mathrm{g} / \mathrm{mg}(n)\end{array}$ \\
\hline Bt11-90 $(\mathrm{Bt}+)$ & $0.0750 \pm 0.0083$ & $72 \pm 9(7)$ \\
Bt11-90 $(\mathrm{Bt}-)$ & $0.0744 \pm 0.0070$ & $83 \pm 8(6)$ \\
Bt11-108 $(\mathrm{Bt}+)$ & $0.0838 \pm 0.0076$ & $98 \pm 14(6)$ \\
Bt11-108 $(\mathrm{Bt}-)$ & $0.0930 \pm 0.0081$ & $73 \pm 8(6)$ \\
Mon810-90 $(\mathrm{Bt}+)$ & $0.0671 \pm 0.0065$ & $90 \pm 7(5)$ \\
Mon810-90 $(\mathrm{Bt}-)$ & $0.0726 \pm 0.0068$ & $87 \pm 8(6)$ \\
Mon810-108 $(\mathrm{Bt}+)$ & $0.0535 \pm 0.0102$ & $91 \pm 8(4)$ \\
Mon810-108 $(\mathrm{Bt}-)$ & $0.0652 \pm 0.0295$ & $87 \pm 6(6)$ \\
Positive control & $0.0963 \pm 0.0227$ & $82 \pm 6(6)$ \\
Negative control & $0.1000 \pm 0.0139$ & $81 \pm 5(5)$ \\
\hline
\end{tabular}

a Values are mean \pm standard error.
Table 5. Average percentage change in mass, growth rate, and average percentage total lipid content of Trachelipus rathkii fed five concentrations of Cry1 Ab protein ${ }^{\mathrm{a}}$

\begin{tabular}{cccr}
\hline $\begin{array}{c}\text { Cry1Ab } \\
(\mu \mathrm{g} / \mathrm{g}) \\
\text { concn. }\end{array}$ & $\begin{array}{c}\text { Mass change } \\
(\%)\end{array}$ & $\begin{array}{c}\text { Growth rate } \\
(\text { slope })\end{array}$ & $\begin{array}{c}\text { Total lipid } \\
\text { concn., } \mu \mathrm{g} / \mathrm{mg} \\
(n)\end{array}$ \\
\hline 0 & $168 \pm 18$ & $0.017 \pm 0.002$ & $80.5 \pm 32.5(4)$ \\
3 & $175 \pm 17$ & $0.017 \pm 0.001$ & $80.4 \pm 18.2(6)$ \\
10 & $168 \pm 17$ & $0.017 \pm 0.002$ & $122.7 \pm 21.1(6)$ \\
40 & $196 \pm 18$ & $0.019 \pm 0.001$ & $68.7 \pm 14.7(7)$ \\
100 & $194 \pm 28$ & $0.018 \pm 0.002$ & $51.0 \pm 25.6(5)$ \\
\hline
\end{tabular}

a Values are mean \pm standard error.

\section{Measurement of energetic reserves}

The average total lipid concentration for each treatment in the A. nasatum assay is reported in Table 3. No statistical differences were observed between any $\mathrm{Bt}$ line and its isoline or between the two control treatments $(p>0.05)$. Additionally, no differences were observed when Bt presence was ignored and the hybrid pairings were compared $(p>0.05)$.

The average total lipid concentration for each treatment in the $T$. rathkii assay is reported in Figure 2. No statistical differences were observed between any Bt line and its isoline or between the two control treatments $(p>0.05)$. Additionally, no differences were observed when Bt presence was ignored and the hybrid pairings were compared $(p>0.05)$.

The average total lipid concentration for the $T$. rathkii in the concentration-response assay is reported in Table 5. No statistical differences in lipid concentration were observed between any of the Cry $1 \mathrm{Ab}$ protein concentration treatments, nor were any of the treatment groups significantly different from the control $(p>0.05)$.

The average concentration of total protein $(\mu \mathrm{g} / \mathrm{mg})$ for each treatment in the pillbug (A. nasatum) assay is reported in Table 3 . None of the treatments were statistically different from the control $(p>0.05)$. Individuals fed Bt11-108 $(\mathrm{Bt}+)$ had a 24 $\pm 8 \mu \mathrm{g} / \mathrm{mg}$ lower concentration of total protein than those fed its isoline $(p=0.0048)$. No other $\mathrm{Bt}-$ isoline pairings were statistically different from one another. When comparisons were made on the basis of corn hybrid pairings, none of the hybrid pairings differed from each other, but the difference

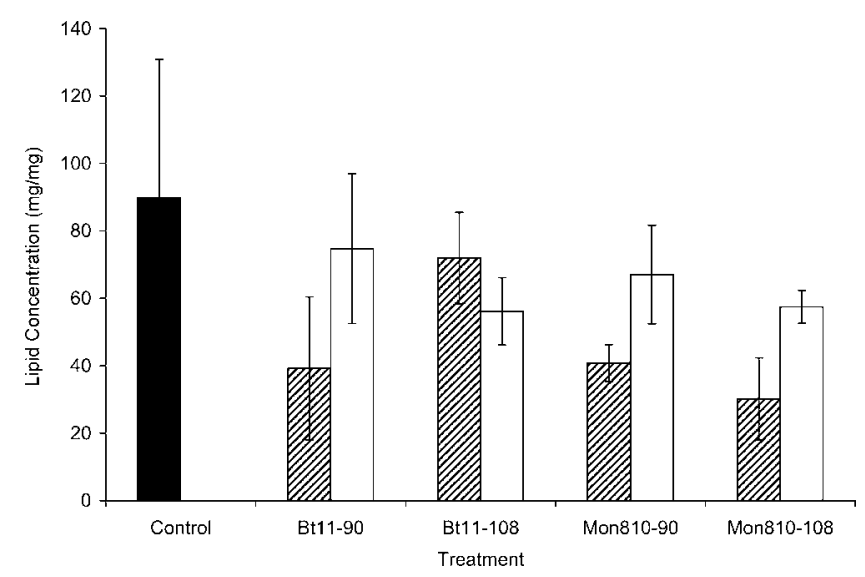

Fig. 2. Average lipid concentration $(\mu \mathrm{g} / \mathrm{mg}$ ) of Trachelipus rathkiifed Bt11 corn, Mon810 corn, or two controls. Black bar, control; hatched bars, Bt corn lines; white bars, isolines. Error bars are equal to standard error. No significant differences exist between any treatments. 
was somewhat close to significant between individuals fed Bt11-108 (Bt \pm ) and two varieties, Mon810-90 (Bt \pm ) and Mon810-108 $(\mathrm{Bt} \pm)(p=0.0659$ and $p=0.0640)$.

The average concentration of total protein $(\mu \mathrm{g} / \mathrm{mg})$ for each treatment in the sowbug ( $T$. rathkii) assay is reported in Table 4. Individuals fed Bt11-108 $(\mathrm{Bt}+)$ had a $24 \pm 12 \mu \mathrm{g} / \mathrm{mg}$ concentration of total protein than those fed its isoline ( $p=$ 0.0479 ). No statistical differences were observed between any of the other treatments, nor did differences exist when Bt presence was ignored and corn varieties were compared $(p>0.05)$.

\section{DISCUSSION}

\section{ELISA measurements of Bt residue in isopods}

The lack of detectable $\mathrm{Bt}$ in the isopods may be due to rapid excretion or digestion of the Cry $1 \mathrm{Ab}$ protein or rapid modification to a form that is not recognizable to the ELISA used. It is also possible that the inability to measure Cry1 Ab protein in the isopods was due to measurement of whole body residue rather than measuring the protein in dissected midguts. Problems could have arisen from interferences within the matrix or dilution due to the amount of buffer needed to extract the whole organism. The detection limit of the ELISA was stated to be around $0.5 \mu \mathrm{g} / \mathrm{L}\left(5 \times 10^{-4} \mu \mathrm{g} / \mathrm{ml}\right)$. This corresponds to around $0.2 \mathrm{mg}$ of consumed corn material at the measured concentrations in Table 1 . It is possible that not enough plant material was consumed by individual isopods to measure the Bt protein. However, as many as 12 individuals were pooled and extracted with $1 \mathrm{ml}$ of the buffer, which would require that one individual only retain about $0.017 \mathrm{mg}$ of plant tissue.

\section{Isopod growth and mortality}

The lack of a deleterious effect of Bt corn material on the isopods $A$. nasatum and $T$. rathkii observed in this test is in agreement with the results of one previous study, although the methodology used in that study was significantly different than in the current study [28]. The author incorporated purified Cry2A protein into the diet of the test subject and measured mortality and growth. This manner of study may be useful for characterizing the potential toxicity of the Bt protein, but it does not accurately model the realistic route of delivery. In the field, the protein is delivered as a component of the plant matter, and exposure is governed primarily by consumption and digestion of the plant material.

In contrast to the results of the current study and those of Sims [28], Escher et al. [29] reported significantly higher juvenile mortality of $P$. scaber reared on the isoline of the Cry1Ab-containing BtX4334 (Novartis). They also observed significantly greater juvenile weight gain over a 131-d period on the Bt foliage than on its isoline. Several possible explanations for the differences between the results exist. Differences in species sensitivity could have had an effect on the observed results. In addition, although the current study used several different varieties of Bt corn and their isolines, Escher et al. [29] examined yet another. They report a higher level of Bt protein in their corn material, which may contribute. If the effects are not caused by the presence of Bt alone, as the current results would suggest, then variability in other parameters between the hybrids could play a role in the effects on growth. It is unclear from their method description how close the isoline was to the $\mathrm{Bt}$ line, as no description of the hybrid was provided. Importantly, the test system used by Escher et al. [29] did not include soil. The current study utilizes agronomic soil with some background microbial activity. These soilborne microbes greatly affect the decomposition process of the corn. Many isopods are known to prefer decaying material to fresh material [36]. In this system, the presence of soil microbes probably increased the rate of decomposition of the corn material. In addition, the microbes themselves provided an enriched food source for the isopods. It is possible that a potential difference in growth or mortality, such as that observed by Escher et al. [29], was alleviated by the presence of the additional microbial activity in the current study. It is known that microbial action increases digestibility of food sources for isopods and that digestibility plays a key role in isopod food preference $[36,37]$.

When compared to the control response, the corn leaf material appeared to be a suitable food source for both isopod species. None of the treatments varied statistically from the control in the A. nasatum assay. Growth measurements were within, at worst, $14 \%$ of the response of the control treatment. The lack of significant differences in growth or molting indicates that the corn varieties used were an acceptable food for $A$. nasatum growth and development. For T. rathkii, more variability existed in the response, and individuals fed several of the corn treatments grew less than the control. Individuals in all the corn treatments grew numerically less than those in the control. However, the two growth measures did not yield identical statistical differences; no differences from controls were observed for the growth rate. These results indicate that if growth in the corn treatments varied from that in the control, it was not to a large degree. It can be concluded that although the corn leaf material was not an ideal food source for $T$. rathkii, it was acceptable. The previous study by Escher et al. [29], in which an isopod was reared on corn leaf material for over $131 \mathrm{~d}$, also supports this conclusion.

\section{Effect of nutritional content}

As stated previously, little variability existed in the average response for any of the treatments in the A. nasatum assay. Because of this, none of the nutritional parameters were found to be a statistically significant factor in the variability between the treatments. The protein, sugar, and fat content were clearly all at suitable levels for this species of pillbug for this length of time. In contrast, greater variability existed between treatments observed in both growth measures for $T$. rathkii, and the nutrition model was significantly correlated with this variability. These results are reinforced by the work of other authors $[29,36,38]$. Lardies et al. [38] reported that dietary protein, more than carbohydrate, was the most important component in determining life history characteristics such as fecundity, growth rate, and offspring size for the isopod Porcellio laevis. The authors also indicated that a diet high in protein and low in carbohydrates would lead to a trade-off between offspring size and number produced. In high-protein situations, the females were more likely to produce more offspring but of smaller size. Additionally, Escher et al. [29] hypothesized that the higher protein and carbohydrate content of the transgenic corn used in their study may have made it of better nutritional quality. Although the corn material used in this assay cannot be considered high in either protein or sugar, it is significantly higher in protein than sugar. Three out of four Bt lines had higher protein content than their corresponding isoline, indicating that without an effect of $\mathrm{Bt}$, the 
higher-protein Bt lines are possibly a better food source for the isopods.

Energetic reserves in $\mathrm{T}$. rathkii and $\mathrm{A}$. nasatum growth and development assays

As stated previously, no statistically significant differences in the lipid measures were observed between any of the treatments in both of the corn-based growth and development assays. However, the variability in the data was very high, particularly in the control treatment. Because the 20 (or fewer) individuals from each treatment were split up into three different groups for the postassay measurements of Bt residue and lipid and protein content, each one of these measures has only four to seven data points per treatment. Interestingly, a trend was observed similar to that seen for growth rate of $T$. rathkii, in which a nonsignificant trend indicated a negative effect of the Bt corn lines. In all treatments, except the Bt11$90 \mathrm{Bt}+$ and $\mathrm{Bt}-$ events, a lower percentage of total lipid existed in the $\mathrm{Bt}+$ events when compared to the isoline events within hybrid varieties. Although not statistically significant, in some cases the isoline treatments yielded numerically double lipid concentrations in $T$. rathkii (Fig. 2).

Significant differences between treatments in total protein content of the isopod body did occur but did not strictly follow the differences observed for the growth measurements as might be expected. Total protein was not statistically different between treatments for $T$. rathkii, the species in which differences in growth were observed, but it was statistically different between treatments for $A$. nasatum, the species in which differences in growth were not observed. Furthermore, for $A$. nastatum, the treatments for which the highest total protein was measured matched those that yielded the highest growth in $T$. rathkii. This may indicate a difference between the two species in response to the same components of nutritional quality that vary between the corn lines. Although no effect on growth was observed, A. nasatum had lower levels of total protein on the same lower-quality foods that produced the depressed growth response in $T$. rathkii.

Previous authors have demonstrated that physiological stress lowers the concentration of energy reserves, in the form of macromolecules such as protein and lipid, using metals and benzo[ $a]$ pyrene $[35,39]$. Relevantly, food quality has also been observed to affect energy reserves [40]. These reserves are especially important in survival for isopods but have also been observed to play a role in growth efficiency [35]. In the current study, differences in total protein for A. nasatum could be an indicator of potential toxic effects of the food treatments on parameters other than growth, such as fecundity or tolerance to starvation.

\section{T. rathkii concentration-response assay}

As described previously, an apparent trend of greater growth of $T$. rathkii on isoline corn (Fig. 1) was somewhat mirrored in the lipid measurements for that species. These results triggered a follow-up concentration-response assay. The results of this assay indicate that this effect was not directly due to the $\mathrm{Bt}$ protein, which agrees with the conclusion of Sims [28]. In the current assay, Cry1 Ab protein did not exert any apparent toxic effect on $T$. rathkii at about 10 times the concentration that commonly occurs in corn plants. By performing a concentration-response assay with purified $\mathrm{Bt}$ protein, it allowed the elimination of the possibility that a trend indicating a small negative effect of the Bt lines versus their isolines was a true effect of the Cry1 Ab protein. This usage of a purified protein concentration-response assay, triggered by the results of the corn-based assay, may be a valuable manner in which to examine potential toxicants in transgenic crops while maintaining a realistic exposure scenario for initial investigation of effects.

\section{CONCLUSION}

Decomposer organisms from the litter and soil environment have not been appreciably studied with respect to the effects of Bt corn despite the great potential for exposure in that realm. Isopods do not generally occur in large numbers in cornfields but do occur in larger numbers in edges with piles of crop litter. They may be best considered here as model arthropod decomposers. The current assay attempts to incorporate a more realistic exposure approach than much of the previous work in nontarget assessment of transgenic crops. It is important to assess the effects of the plant material rather then purified $\mathrm{Bt}$ protein alone. These assays allow characterization of effects that are not directly caused by the Bt protein itself. Furthermore, nontarget organism exposure to Bt proteins is governed largely by the release of $\mathrm{Bt}$ from plant matter as it decomposes or by the consumption of this plant matter. This exposure route is not properly represented in tests using purified Bt protein. A further improvement of these assays on many previous methods for nontarget-effects assessment of Bt crops is the use of a wider range of corn varieties. This allows for differences between varieties that are not directly related to $\mathrm{Bt}$ (i.e., nutritional quality) to be placed in a larger context of the variability between multiple corn hybrids as opposed to a single comparison between one $\mathrm{Bt}$ line and one isoline. Additionally, any observed negative effect of a Bt line compared to its isoline that is not actually an effect of $\mathrm{Bt}$ is more easily determined using multiple Bt varieties (hybrids and/or events) and their isolines. One major disadvantage of using plant material is that it does not allow for testing of multiple concentration levels of protein. This can be alleviated to a degree by testing multiple corn varieties with some variability in Bt-protein concentration. However, if a potential effect of the Bt protein is observed across multiple corn varieties, it may still be advisable to conduct a dose- or concentration-response test with purified Bt protein. It is also important in these assays with transgenic plant material to use multiple controls as was attempted here. The use of an isoline is obviously a necessary control for the effect of the Bt protein, but an optimal food is important as a control to indicate the baseline optimal response of the organism.

Overall, these results indicate that the Cry1 Ab protein within several corn lines does not affect the survival and growth of A. nasatum and T. rathkii. However, these results do indicate that differences between some Bt lines and their isolines or between some corn varieties can have an effect on the growth and energetic reserves for isopods. Differences in nutritional factors and suitability for degrader populations may play an important role in how transgenic crops affect the agroecosystem. These effects are observable only in assays that use the transgenic plant material rather than purified protein alone.

Acknowledgement-The authors thank Richard Hellmich, Joan Jass, the Iowa Agriculture Experiment Station, and the U.S. Department of Agriculture-Agricultural Research Service. 


\section{REFERENCES}

1. Flexner JL, Lighthart B, Croft BA. 1986. The effects of microbial pesticides on non-target, beneficial arthropods. Agric Ecosyst Environ 16:203-254.

2. Obrycki JJ, Losey JE, Taylor OR, Jesse LCH. 2001. Transgenic insecticidal corn: Beyond insecticidal toxicity to ecological complexity. BioScience 51:353-361.

3. James C. 2002. Global status of commercialized transgenic crops: 2002. ISAAA Brief, No. 27. International Service for the Acquisition of Agri-biotech Applications, Ithaca, NY, USA.

4. James C. 2003. Global status of commercialized transgenic crops: 2003. ISAAA Brief, No. 30. International Service for the Acquisition of Agri-biotech Applications, Ithaca, NY, USA.

5. Saxena D, Stotzky G. 2000. Insecticidal toxin from Bacillus thuringiensis is released from roots of transgenic $B t$ corn in vitro and in situ. FEMS Microbiol Ecol 33:35-39.

6. Venkateswerlu G, Stotzky G. 1992. Binding of the protoxin and toxin proteins of Bacillus thuringiensis subsp. kurstaki on clay minerals. Curr Microbiol 25:1-9.

7. Tapp H, Calamai L, Stotzky G. 1994. Adsorption and binding of the insecticidal proteins from Bacillus thuringiensis subsp. kurstaki and subsp. tenebrionis on clay minerals. Soil Biol Biochem 26:663-679.

8. Tapp H, Stotzky G. 1995. Insecticidal activity of the toxins from Bacillus thuringiensis subspecies kurstaki and tenebrionis adsorbed and bound on pure and soil clays. Appl Environ Microbiol 61:1786-1790.

9. Tapp H, Stotzky G. 1998. Persistence of the insecticidal toxin from Bacillus thuringiensis subsp. kurstaki from soil. Soil Biol Biochem 30:471-476.

10. Koskella J, Stotzky G. 1997. Microbial utilization of free and clay-bound insecticidal toxins from Bacillus thuringiensis and their retention of insecticidal activity after incubation with microbes. Appl and Environ Microbiol 63:3561-3568.

11. Palm CJ, Donegan K, Harris D, Seidler RJ. 1994. Quantification in soil of Bacillus thuringiensis var. kurstaki $\delta$-endotoxin from transgenic plants. Mol Ecol 3:145-151.

12. Palm CJ, Schaller DL, Donegan KK, Seidler RJ. 1996. Persistence in soil of transgenic plant produced Bacillus thuringiensis var. kurstaki delta-endotoxin. Can J Microbiol 42:1258-1262.

13. Sims SR, Ream JE. 1997. Soil inactivation of the Bacillus thuringiensis subsp. kurstaki CryIIA insecticidal protein within transgenic cotton tissue: laboratory and field studies. J Agric Food Chem 45:1502-1505.

14. Herman RA, Wolt JD, Halliday WR. 2002. Rapid degradation of the Cry1F insecticidal crystal protein in soil. J Agric Food Chem 50:7076-7078.

15. Zwahlen C, Hilbeck A, Gugerli P, Nentwig W. 2003. Degradation of the Cry $1 \mathrm{Ab}$ protein within the transgenic Bacillus thuringiensis corn tissue in the field. Mol Ecol 12:765-775.

16. Saxena D, Stotzky G. 2001. Bacillus thuringiensis (Bt) toxin released from root exudates and biomass of Bt corn has no apparent effect on earthworms, nematodes, protozoa, bacteria, and fungi in soil. Soil Biol Biochem 33:1225-1230.

17. Zwahlen C, Hilbeck A, Howald R, Nentwig W. 2003. Effects of transgenic corn litter on the earthworm Lumbricus terrestris. Mol Ecol 12:1077-1086.

18. Sims SR, Martin JW. 1997. Effect of the Bacillus thuringiensis insecticidal proteins CryIA(b), CryIA(c), CryIIA, and CryIIIA on Folsomia candida and Xenylla grisea (Insecta: Collembola). Pedobiologia 41:412-416.

19. Yu L, Berry RE, Croft BA. 1997. Effects of Bacillus thuringiensis toxins in transgenic cotton and potato on Folsomia candida (Collembola: Isotomidae) and Oppia nitens (Acari: Oribatidae). $J$ Econ Entomol 90:113-118.

20. Donegan KK, Palm CJ, Fieland VJ, Porteous LA, Ganio LM, Schaller DL, Bucao LQ, Seidler RJ. 1995. Changes in levels, species, and DNA fingerprints of soil microorganisms associated with cotton expressing the Bacillus thuringiensis var. kurstaki endotoxin. Appl Soil Ecol 2:111-124.

21. Donegan KK, Schaller DL, Stone JK, Ganio LM, Reed G, Hamm PB, Seidler RJ. 1996. Microbial populations, fungal species diversity and plant pathogen levels in field plots of potato plants expressing the Bacillus thuringiensis var. tenebrionis endotoxin. Transgenic Res 5:25-35.

22. Hornung E, Farkas S, Fischer E. 1998. Tests on the isopod Porcellio scaber. In Lokke H, van Gestel CAM, eds, Handbook of Soil Invertebrate Toxicity Tests. John Wiley, Chichester, UK, pp 207-226.

23. Drobne D. 1997. Terrestrial isopods-A good choice for toxicity testing of pollutants in the terrestrial environment. Environ Toxicol Chem 16:1159-1164.

24. Warburg MR. 1993. Evolutionary Biology of Land Isopods. Springer-Verlag, Berlin, Germany, pp 1-151.

25. Hassall M, Turner JG, Rands MRW. 1987. Effects of terrestrial isopods on the decomposition of woodland leaf litter. Oecologia 72:597-604.

26. Gunnarsson T, Tunlid A. 1986. Recycling of faecal pellets in isopods: Microorganisms and nitrogen compounds as potential food for Oniscus asellus L. Soil Biol Biochem 18:595-600.

27. Jass J, Klausmeier B. 1996. Terrestrial isopods (Isopoda: Oniscidea) of Wisconsin. Gt Lakes Entomol 29:11-20.

28. Sims SR. 1997. Host activity spectrum of the CryIIA Bacillus thuringiensis subsp kurstaki protein: Effect on Lepidoptera, Diptera, and non-target arthropods. Southwest Entomol 22:395-404.

29. Escher N, Kach B, Nentwig W. 2000. Decomposition of transgenic Bacillus thuringiensis maize by microorganisms and woodlice Porcellio scaber (Crustacea: Isopoda). Basic Appl Ecol $1: 161-169$

30. Fearing PL, Brown D, Vlachos D, Meghji M, Privalle L. 1997. Quantitative analysis of CryIA(b) expression in Bt maize plants, tissues, and silage and stability of expression over successive generations. Mol Breed 3:169-176.

31. U.S. Department of Agriculture-Natural Resource Conservation Service. 2003. Keys to Soil Taxonomy, 9th ed. Washington, DC.

32. AOAC International. 2000. Fat (total, saturated, and unsaturated) in foods, method 996.06. In Horowitz W, ed, Official Methods of Analysis of AOAC International, 17th ed. Gaithersburg, MD, USA, Ch. 41, pp 20-24.

33. AOAC International. 2000. Protein (crude) in animal food, method 954.01. In Horowitz W, ed, Official Methods of Analysis of AOAC International, 17th ed. Gaithersburg, MD, USA, Ch. 4, p 20.

34. AOAC International. 2000. Separation of sugars in honey, method 977.20. In Horowitz W, ed, Official Methods of Analysis of AOAC International, 17th ed. Gaithersburg, MD, USA, Ch. 44, pp 4344.

35. Donker MH. 1992. Energy reserves and distribution of metals in populations of the isopod Porcellio scaber from metal-contaminated sites. Funct Ecol 6:445-454.

36. Zimmer M. 2002. Nutrition in terrestrial isopods (Isopoda: Oniscidea): An evolutionary-ecological approach. Biol Rev 77:455493.

37. Hassall M, Rushton SP. 1984. Feeding behaviour of terrestrial isopods in relation to plant defences and microbial activity. In Hutton SL, Holdrich DM, eds, The Biology of Terrestrial Isopods, Symposia of the Zoological Society of London, No. 53. Oxford University Press, Oxford, UK, pp 487-505.

38. Lardies MA, Carter MJ, Bozinovic F. 2004. Dietary effects on life history traits in a terrestrial isopod: The importance of evaluating maternal effects and trade-offs. Oecologia 138:387-395.

39. Van Brummelen TC, Stuijfzand SC. 1993. Effects of benzoapyrene on survival, growth, and energy reserves in the terrestrial isopods Oniscus asellus and Porcellio scaber. Sci Total Environ (Suppl):921-930.

40. Steinberger Y. 1989. Energy and protein budgets in the desert isopods Hemilepistus reamuri. Acta Oecol Oecol Gen 10:117134. 